Scientific Review - Engineering and Environmental Sciences (2021), 30 (3), 464-476

Sci. Rev. Eng. Env. Sci. (2021), 30 (3)

Przegląd Naukowy - Inżynieria i Kształtowanie Środowiska (2021), 30 (3), 464-476

Prz. Nauk. Inż. Kszt. Środ. (2021), 30 (3)

http://iks.pn.sggw.pl

DOI 10.22630/PNIKS.2021.30.3.39

Haider M. OWAID, Muna M. Al-RUBAYE, Haider M. Al-BAGHDADI

University of Babylon, College of Engineering

\title{
Use of waste paper ash or wood ash as substitution to fly ash in production of geopolymer concrete
}

Key words: geopolymer concrete (GC), fly ash (FA), waste paper ash (WPA), wood ash (WA), alkaline solution

\section{Introduction}

Concrete is the most popular and widely used building material owing to availability of its raw materials and it combines good mechanical properties, durability, workability and it is relatively inexpensive. Ordinary Portland cement (OPC) is the key constituent binding material used in the concrete production, however manufacturing of OPC contributes substantially to global $\mathrm{CO}_{2}$ emissions and energy consumption (Fairbairn et al., 2010). The main causes of high $\mathrm{CO}_{2}$ emissions, which is known as the greenhouse gas rising from manufacturing of OPC have been attributed to the process of calcination of limestone and high energy consumption (Davidovits, 2011; Turner \& Collins, 2013). Con- crete is mainly used in the construction of buildings in civil engineering applications and infrastructure projects. Hence, the construction of buildings is under increasing pressure of developing green binder materials that possess the desired engineering properties to overcome the $\mathrm{CO}_{2}$ emission and reduce the dependence on the OPC (Małaszkiewicz \& Jastrzębski, 2018; Abdulkareem, Ramli \& Matthews, 2019). Several alternative cementitious materials that are principally derived from industrial by-products can provide comparable performance to the OPC in a range of applications, but with an additional advantage of significantly reduced greenhouse emissions (Gartner, 2004). The alternative materials involve sugar cane bagasse ash (SCBA), fly ash (FA), metakaolin (MK), rice hush ash (RHA), blast furnace slag (BFS), vulcanic ash and bottom ash (BA) (Fernandez-Jimenez, Palomo \& Lopez-Hombrados, 2006; Fairbairn et al., 2010; Risdanareni, Karjanto \& Khakim, 2016; 
Thaarrin \& Ramasamy, 2016; Ekaputri \& Junaedi, 2017; Mehta and Siddique, 2018), which contain much silica $\left(\mathrm{SiO}_{2}\right)$ and alumina $\left(\mathrm{Al}_{2} \mathrm{O}_{3}\right)$. The most popular of these materials that considered in manufacturing GC is fly ash (FA), which is residue from the burnt coal, and it is available worldwide as a waste material (Ryu, Lee, Koh \& Chung, 2013). An alternative concrete termed "geopolymer concrete" (GC) that based on one of the by-product materials as a substitute for OPC has been considered as environmentally friendly concrete (Hardjito, Wallah, Sumajouw \& Rangan, 2004).

This concrete is formed by the alkaline activation of the aforementioned by-products materials to form an aluminosilicate gel structure through the polycondensation reaction. The alkaline activator used is commonly a combination of a hydroxyl, usually sodium hydroxide $(\mathrm{NaOH})$ or potassium hydroxide $(\mathrm{KOH})$ and sodium silicate $\left(\mathrm{Na}_{2} \mathrm{SiO}_{3}\right)$ or potassium silicate (Turner \& Collins, 2013). Besides, it is required to provide curing for $\mathrm{GC}$ with elevated temperature between $40^{\circ} \mathrm{C}$ and $80^{\circ} \mathrm{C}$ for at least $6 \mathrm{~h}$ to achieve an equivalent strength to OPC concrete (Duxson et al. 2007; Ryu et al. 2013). Beside the interest in finding low $\mathrm{CO}_{2}$ emission and low energy consumption binders there is an interest in investigating the possibility of using the waste materials as the substitutes for OPC in producing of geopolymer concretes (Shi, Wu, Riefler \& Wang, 2005). The construction industry offers reusability solutions for wastes due to the large consumption of materials and the large number of construction sites, thereby, in many developed economies, waste represents a resource that can be utilized for a diversity of beneficial purposes (Tam, Soomro \& Evangelista, 2018). Huge amounts of paper and wood waste are generated every day due to the increase of production and population, the disposal of these waste to landfill is expensive in addition to the scarcity of suitable land that cause a number of pollution and environmental problems. Consequently, an economical alternative to landfill disposal is by reusing of waste materials, the waste reusability has many advantages, including the decrease in the waste volumes, the reduction of greenhouse gas emissions and the consumption of natural resources (Letelier, Henriquez-Jara, Manosalva \& Moriconi, 2019).

Previous research has been published concerning the influence of using paper sludge ash on the properties of concrete and paste (Ishimoto, Origuchi \& Yasuda, 2000; Bai et al., 2003; Frías, Garcia, Vigil \& Ferreiro, 2008; García, de la Villa, Vegas, Frias \& de Rojas, 2008; Mozaffari, Kinuthia, Bai \& Wild, 2009). According to Pachamuthu and Thangaraju (2017), the improvement of the mechanical properties of GC that contains paper sludge ash depends on the percentages of paper sludge ash and the curing conditions. On the other hand, several studies (Etiegni \& Campbell, 1991; Naik, Kraus \& Siddique, 2003; Udoeyo, Inyang, Young \& Oparadie, 2006; Chowdhury, Maniar \& Suganya, 2015) were conducted to investigate the feasibility of the use of wood ash as a partial replacement material to OPC in making of blended mortar or concrete. This paper presents the feasibility of incorporating of waste paper ash (WPA) or wood ash (WA) as replacement materials for fly ash (FA) 
(class F) in preparation geopolymer concrete (GC). The influence of the WPA or WA incorporation on the geopolymers' workability, compressive strength, splitting tensile strength and flexural strength has been studied and compared with neat FA geopolymer as a control mix.

\section{Materials}

\section{Fly ash (FA), waste paper ash (WPA) and wood ash (WA)}

In this study, fly ash FA (class F) that collected from Turkish hard coal from power station Iskenderun was used to produce GC mixes, the specific gravity of FA was $2.21 \mathrm{~g} \cdot \mathrm{cm}^{-3}$. It conforms to the ASTM standard specification C618-08a (ASTM International [ASTM], 2008). The waste paper ash (WPA) is a leftover material that has found in large quantities worldwide within offices, government departments and houses. The waste paper ash used for this study was collected from burning in oven up to $650 \pm 20^{\circ} \mathrm{C}$, for $60 \mathrm{~min}$, it has a specific gravity of $2.53 \mathrm{~g} \cdot \mathrm{cm}^{-3}$. Besides, wood ash (WA) obtained from industrial by-product such wood burning, it has a specific gravity of $2.31 \mathrm{~g} \cdot \mathrm{cm}^{-3}$. The chemical composition of FA, WPA and WA are listed in Table 1.

\section{Fine and coarse aggregate}

The fine aggregate used was natural river sand, free from loam and clay. The fine aggregate having specific gravity of $2.66 \mathrm{~g} \cdot \mathrm{cm}^{-3}$, with sulfate content of $0.23 \%$ and the grading of fine aggregate satisfies the requirements of Iraqi standard IQS 45/1984 (Iraqi Central Agency for Standardization and Quality Control [ICASQC], 1984) (Zone 2). While, the crushed gravel was used in this study with maximum size of $19 \mathrm{~mm}$. The coarse aggregate having a specific

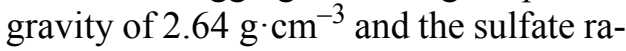
tio of $0.04 \%$ and it conforms to the IQS 45/1984 standard.

\section{High-water range reducer}

A high-water range reducer (SP400) has been utilized to enhance the workability of GC. It complies with the ASTM C494-C494M standard (ASTM, 2017).

\section{Alkaline activator liquid}

The alkaline liquid was obtained by blending solutions of sodium hydroxide and sodium silicate to activate the fly ash. Sodium hydroxide has flakey form and high purity more than $98 \%$, which could be dissolved in the filtered water (molarity of solution of sodium hydro-

TABLE 1. Chemical composition of fly ash (FA), waste paper ash (WPA) and wood ash (WA)

\begin{tabular}{|l|c|c|c|c|c|c|c|c|c|}
\hline $\begin{array}{l}\text { Oxides } \\
{[\%]}\end{array}$ & $\mathrm{SiO}_{2}$ & $\mathrm{AL}_{2} \mathrm{O}_{3}$ & $\mathrm{Fe}_{2} \mathrm{O}_{3}$ & $\mathrm{CaO}$ & $\mathrm{MgO}$ & $\mathrm{Na}_{2} \mathrm{O}$ & $\mathrm{K}_{2} \mathrm{O}$ & $\mathrm{SO}_{3}$ & L.OI \\
\hline FA & 65.65 & 17.69 & 5.98 & 0.98 & 0.72 & 1.35 & 2.99 & 0.19 & 3.1 \\
\hline WPA & 47.80 & 27.00 & 2.34 & 6.53 & 3.32 & 3.50 & 6.38 & 1.10 & 1.13 \\
\hline WA & 32.51 & 28.30 & 2.14 & 9.53 & 3.32 & 10.50 & 12.3 & 0.10 & 22.50 \\
\hline
\end{tabular}


xide (10M). The sodium silicate $\mathrm{Na}_{2} \mathrm{SiO}_{3}$ as a solution is commercially available.

\section{Experimental program}

The experimental program consists of preparing and testing different GC mixes to examine the influence of incorporating WPA or WA on the properties of GC. The developed GC mixes for this study were prepared at replacement ratios of FA by WPA or WA of 25, 50, 75 and $100 \%$ in addition to a control mix containing $100 \%$ of FA. The tested mixes have been evaluated with respect to the workability, the compressive strength at ages of the tested specimens of 7,28 and 56 days. Tensile splitting strength and flexural strength at age of the 28 days.

\section{Mix proportions of GC mixes}

Based on the geopolymer concrete mix designed by Rangan (2008), the
GC mix was developed taken into account the workability and the ratio of silicate-sodium to sodium hydroxide solution was 2.5 . The density of GC was $2,400 \mathrm{~kg} \cdot \mathrm{cm}^{-3}$. The mix proportions of all GC mixes are illustrated in Table 2.

\section{Preparation of test specimens}

The binder (FA, WPA or WA) was dry mixed with the fine and coarse aggregates using pan mixer for $4 \mathrm{~min}$. Then, the superplasticizer dosages (SP) and the prepared alkaline activator liquid used of the GC mixes were mixed for 2 min and added gradually to the solid ingredients. Afterwards, the wet mixing continued for $5 \mathrm{~min}$ more until the mix was homogenized. For the workability evaluation, the fresh GC mixes were tested using slump test. The slump test was performed in accordance with the ASTM C143/C143M-05a standard (ASTM, 2005).

TABLE 2. Mix proportions of test GC mixes $\left[\mathrm{kg} \cdot \mathrm{m}^{-3}\right]$

\begin{tabular}{|l|c|c|c|c|c|c|c|c|c|}
\hline Mix symbol & FA & $\begin{array}{c}\text { Repl. } \\
{[\%]}\end{array}$ & WPA & WA & $\mathrm{Fa}^{*}$ & $\mathrm{Ca}^{* *}$ & $\begin{array}{c}\text { Alkaline } \\
\text { liquid }\end{array}$ & $\begin{array}{c}\text { Alkaloid } \\
\text { to } \\
\text { binder } \\
\text { ratio }\end{array}$ & SP \\
\hline GF-0 & 404 & 0 & 0 & 0 & 660 & 1100 & 176 & 0.43 & 9 \\
\hline GF-P25 & 303 & 25 & 101 & - & 660 & 1100 & 176 & 0.43 & 9 \\
\hline GF-P50 & 202 & 50 & 202 & - & 660 & 1100 & 176 & 0.43 & 9 \\
\hline GF-P75 & 101 & 75 & 303 & - & 660 & 1100 & 176 & 0.43 & 9 \\
\hline GF-P100 & 0 & 100 & 404 & - & 660 & 1100 & 176 & 0.43 & 9 \\
\hline GF-W25 & 303 & 25 & - & 101 & 660 & 1100 & 176 & 0.43 & 9 \\
\hline GF-W50 & 202 & 50 & - & 202 & 660 & 1100 & 176 & 0.43 & 9 \\
\hline GF-W75 & 101 & 75 & - & 303 & 660 & 1100 & 176 & 0.43 & 9 \\
\hline GF-W100 & 0 & 100 & - & 404 & 660 & 1100 & 176 & 0.43 & 9 \\
\hline
\end{tabular}

*fine aggregate, $* *$ coarse aggregate. 
For evaluating the compressive, splitting tensile and flexural strengths, the fresh GC mixes were cast into cubic moulds of $100 \mathrm{~mm}$, cylindrical moulds of $100 \times 200 \mathrm{~mm}$ and prism moulds of $100 \times 100 \times 400 \mathrm{~mm}$. After casting, the specimens were vibrated for 2 min on the vibration table to remove entrapped air. Thereafter, the moulded specimens were covered using a plastic sheet to prevent water evaporation. According to Rangan (2008), the effective curing temperature is $60^{\circ} \mathrm{C}$, thus the specimens were then cured in an oven at a temperature of $60^{\circ} \mathrm{C}$ for one day.

Finally, the specimens have been left at room temperature until the testing date. The compressive strength test was conducted in accordance the BS 1881-116:1983 standard (British Standards Institute [BSI], 1983), while the splitting tensile strength was conducted according to the ASTM C496 standard (ASTM, 2004), and the flexural strength test was conducted according to the ASTM C78 standard (ASTM, 2002).

\section{Results and discussion}

\section{Workability of GC mixes}

The workability of all fresh GC mixes was measured immediately after mixing using slump test as for the conventional concrete. The SP was used to achieve the required slump with a dosage of $2.25 \%$ by weight of binder for all types of GC mixes and the liquid/binder ratio was kept of 0.43 for all the $\mathrm{GC}$ mixes. The slump values for all GC mixes were ranged from $98-104 \mathrm{~mm}$ as summarized in Table 3, the results showed there were no significant differences in the slump values for all GC mixes.

TABLE 3. The slump of GC mixes

\begin{tabular}{|l|c|}
\hline Mix symbol & Slump $[\mathrm{mm}]$ \\
\hline GF-0 & 104 \\
\hline GF-P25 & 98 \\
\hline GF-P50 & 101 \\
\hline GF-P75 & 100 \\
\hline GF-P100 & 102 \\
\hline GF-W25 & 99 \\
\hline GF-W50 & 103 \\
\hline GF-W75 & 101 \\
\hline GF-W100 & 99 \\
\hline
\end{tabular}

\section{Mechanical properties of GC mixes}

The results of the compressive, splitting tensile and flexural strengths of GC specimens are in Table 4 . The results of compressive strength of $\mathrm{GC}$ specimens were at ages of 7,28 and 56 days and Figures 1 and 2 display the variations of compressive strength as the proportional percentages of compressive strength GC mixes to the control GC mixes (GF-0). As observed from Table 4 that the control mix GF-0 (100\% FA) developed the highest compressive strength than the other blended mixes containing WPA or WA at the all ages, and the compressive strength of the control specimens increased after extended aging to 56 days. Results also show a small decrease in the compressive strength for GC mixes that incorporation WPA of 25\% (GF-P25) at the all-tested ages and 50\% (GF-P50) at 7 and 28 days in comparison with the GF-0. Whereas the GF-P50 at 56 days has more decrease in compressive strength as compared to the GF- 0 . 
TABLE 4. Test results of the mechanical properties of GC mixes properties

\begin{tabular}{|c|c|c|c|c|c|}
\hline \multirow[t]{2}{*}{ Mix symbol } & \multicolumn{3}{|c|}{$\begin{array}{c}\text { Compressive strength } \\
{[\mathrm{MPa}]}\end{array}$} & \multirow{2}{*}{$\begin{array}{c}\text { Splitting tensile } \\
\text { strength } \\
\text { [MPa] }\end{array}$} & \multirow{2}{*}{$\begin{array}{c}\begin{array}{c}\text { Flexural strength } \\
{[\mathrm{MPa}]}\end{array} \\
28 \text { days }\end{array}$} \\
\hline & 7 days & 28 days & 56 days & & \\
\hline GF-0 & 42.38 & 57.73 & 61.51 & 3.52 & 4.85 \\
\hline GF-P25 & 42.00 & 56.78 & 59.86 & 3.41 & 4.77 \\
\hline GF-P50 & 41.82 & 55.53 & 56.88 & 3.21 & 5.02 \\
\hline GF-P75 & 39.18 & 52.43 & 52.26 & 3.10 & 4.35 \\
\hline GF-P100 & 35.12 & 49.28 & 50.37 & 2.93 & 4.10 \\
\hline GF-W25 & 41.10 & 55.24 & 57.82 & 2.92 & 4.55 \\
\hline GF-W50 & 34.11 & 49.27 & 53.58 & 2.54 & 4.35 \\
\hline GF-W75 & 29.22 & 43.13 & 47.75 & 2.30 & 3.83 \\
\hline GF-W100 & 20.00 & 39.5 & 44.21 & 2.10 & 3.17 \\
\hline
\end{tabular}

On the other hand, excluding the creases in compressive strength appear GC mix incorporation WA of $25 \%$ in the mixes $100 \%$ WPA (GF-P100) (GF-W25) at ages of 7 and 28 days, or $100 \%$ WA (GF-W100) compared to the GC mixes inclusion WA of 50, 75 those of the control mixes (GF-0) at all and 100\% (GF-W50, GF-W75 and tested ages. The compressive strength of GF-W100) have the lowest compressive the control mixes decreases by about 14 , strength at all tested ages in comparison 17.6 and $18 \%$ and $52.8,31.6$ and $28 \%$ in to GF-0 mix. Besides, it can be seen from the GC mixes incorporation $100 \%$ WPA Figures 1 and 2 that the most notable de- or $100 \%$ WA at 7, 28 and 56 days

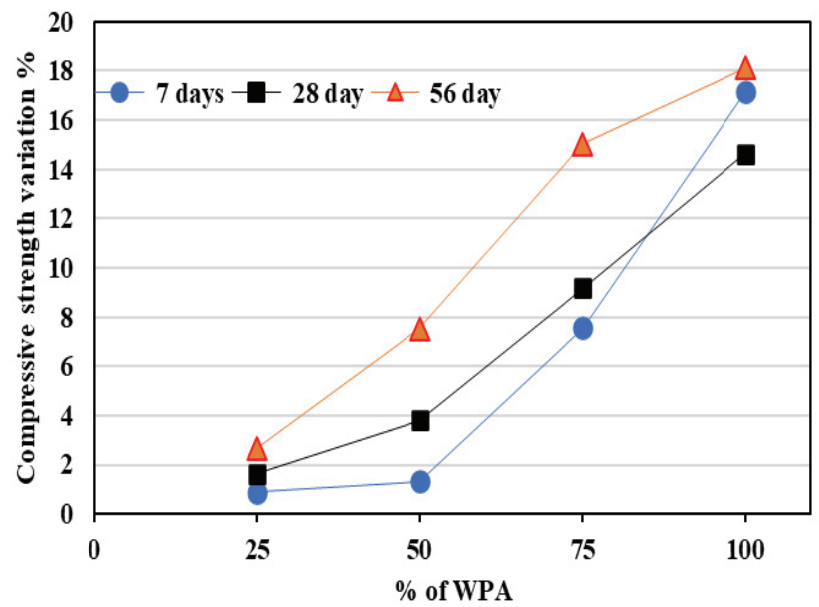

FIGURE 1. Compressive strength variation of GC mixes with replacement of FA by WPA 


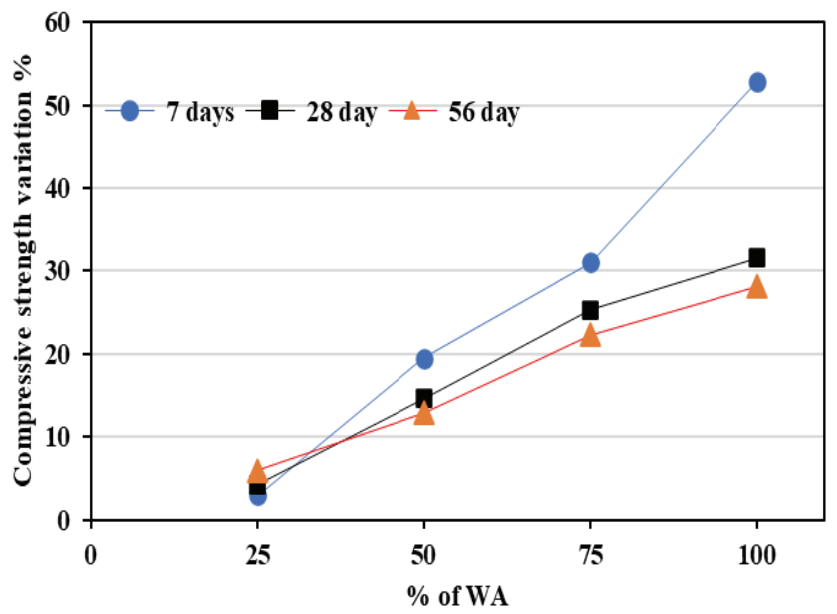

FIGURE 2. Compressive strength variation of GC mixes with replacement of FA by WA

respectively. Moreover, the reduction in compressive strength for $\mathrm{GC}$ mixes inclusion WA is more obvious than in mixes inclusion WPA. This may be due to the concentration of silicate through WPA more than WA, which affects the strength development due to higher silicates availability for the polymerization (Fernández-Jiménez, García-Lodeiro \& Palomo, 2007). Also, the high $\mathrm{CaO}$ content present in WA causes reduction in strength of GC mixes (Astutiningsih and Liu, 2005; Luga \& Peqini, 2019). Generally, the reduction of compressive strength for GC mixes as the replacement percentages of WPA or WA are increased, is justified due to the slower dissolution rate of WPA and WA in comparison with that high dissolution rates of the FA aluminosilicate, which has an impact on the strength development; as a result of reducing the silicon and aluminium ions (Shi et al., 2005).

The results of the splitting tensile strength of the GC specimens at age of 28 days are given in Table 4. Figure 3 displays the variations of splitting tensile strength as proportional percentages to the control mixes GF- 0 . As can be observed from these results that the splitting tensile strength of the control mix GF-0 $(100 \% \mathrm{FA})$ developed the highest splitting tensile strength than the other blended mixes containing WPA or WA. The splitting tensile strength of the GC mixes inclusion WPA or WA reduced with increasing WPA and WA contents and the reductions were more pronounced when compared with reductions in compressive strength.

The splitting tensile strength of the control mix decreases by about 16.8 and $40.3 \%$ in the GC mixes incorporation $100 \% \mathrm{WPA}$ or $100 \% \mathrm{WA}$ respectively. Besides, the GC mixes inclusion WA showed lower values of the splitting tensile strength as compared to those obtained for GC mixes inclusion WPA.

The flexural strength results of the studied GC specimens at 28 days are presented in Table 4 and Figures 4 and 5. It is evident from the test results that the use of WPA or WA resulted in decrease in the flexural strength with 


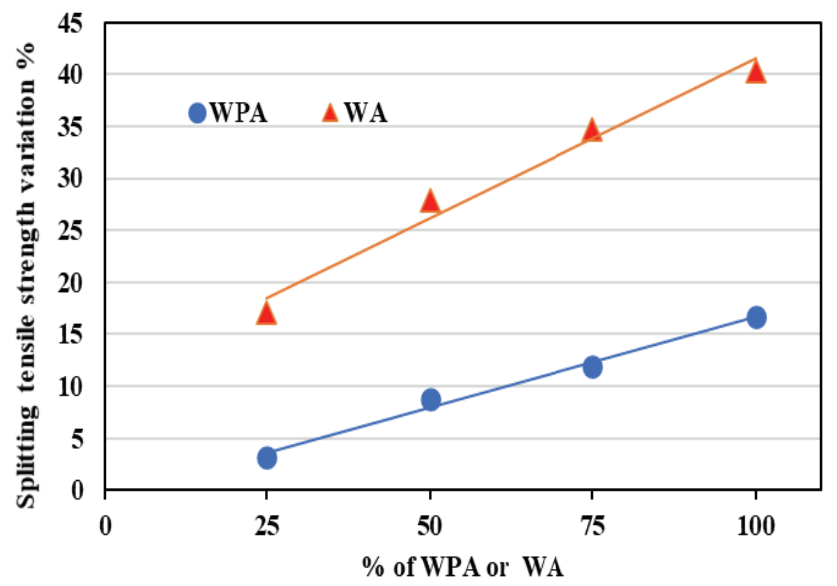

FIGURE 3. Splitting tensile strength variation of GC mixes with replacement of FA by WPA or WA

increasing WPA or WA contents excluding the GC mix with 50\% WPA, which exhibited flexural strength greater than that of the control mix (GF-0). Further, the reductions in flexural strengths for GC mixes inclusions WPA or WA are close to those reductions in compressive strength for these mixes and less than the reductions in splitting tensile strength.

Figures 6 and 7 show the studied strength parameters (compressive strength, splitting tensile strength and flexural strength) at age of 28 days for GC mixes with replacement of FA by WPA or WA respectively. The decrease in the strength parameters occurred as the WPA or WA contents increase, which, can attributed to the silicate and aluminate contents and low value of pozzolanic reactivity of WPA and WA. Moreover, the reduction is more pronounce in GC mixes inclusion WA due to high content of $\mathrm{CaO}$ present in WA.

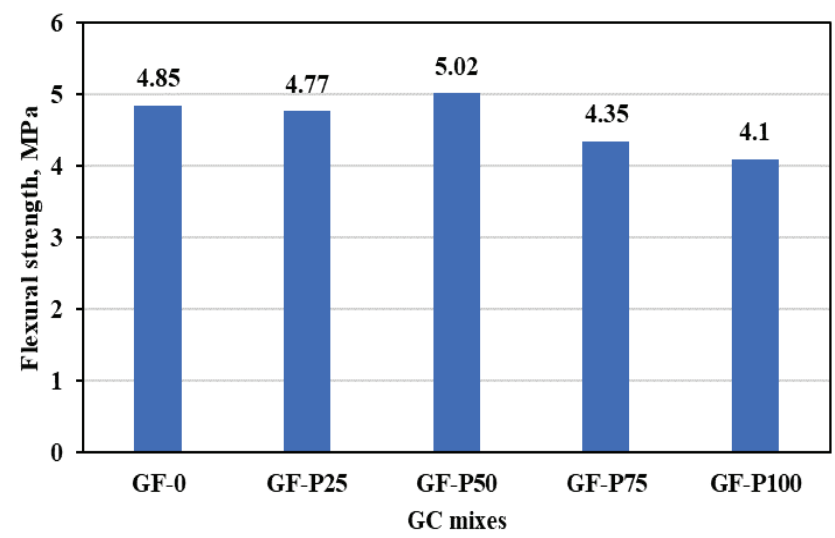

FIGURE 4. The flexural strength of the GC mixes with replacement of FA by WPA 


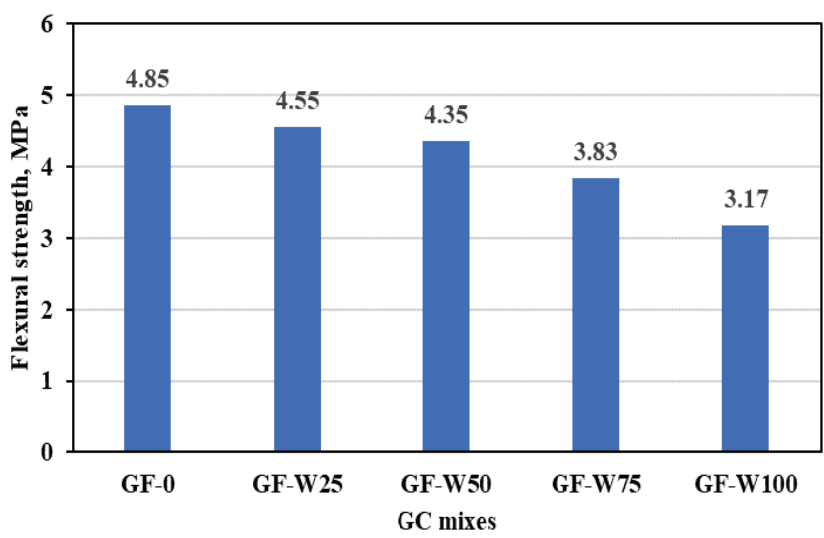

FIGURE 5. The flexural strength of the GC mixes with replacement of FA by WA

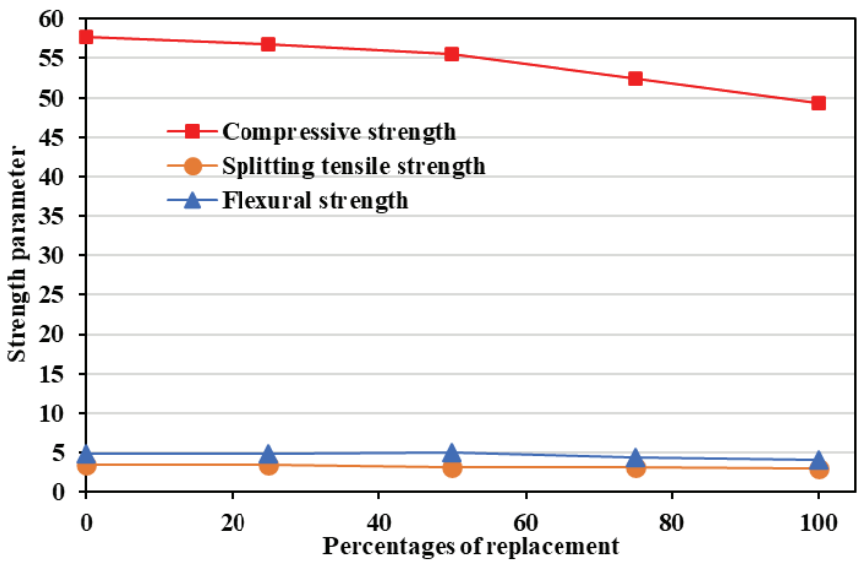

FIGURE 6. Strength parameters at 28 days for GC mixes with replacement of FA by WPA

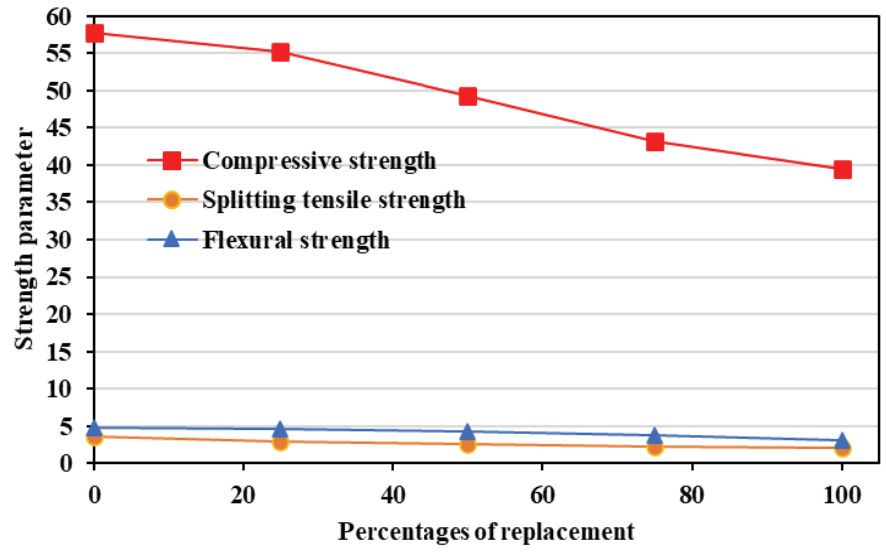

FIGURE 7. Strength parameters at 28 days for GC mixes with replacement of FA by WA 


\section{Conclusions}

The properties of GC made with WPA from offices, and houses and WA from industrial waste replacing FA class $\mathrm{F}$ in absolute volume percentages up to $100 \%$ was evaluated in this study. The main conclusions are as follows:

- The results of the workability showed that there were no significant differences in the slump values of developed GC mixes with WPA or WA and the control GC mix (GF-0).

- The results of the development compressive strength of GC mixes inclusion $25-50 \%$ of WPA are close when compared with compressive strength of control mix of (GF-0). Replacement of $75-100 \%$ of WPA caused a further decrease in compressive strength of the GC mixes.

- The replacement with $25 \%$ WA had little effect on the compressive strength of GC mixes, while replacement with 50, 75 and 100\% WA resulted in more reduction in the compressive strength of GC mixes in comparison with the control mix (GF-0).

- The splitting tensile strength of the GC mixes inclusion WPA is influenced with increasing WPA content, and the inclusion of WA as replacement for FA negatively affected the splitting tensile strength. The reductions in splitting tensile strength are more pronounced than the reductions in compressive and in flexural strengths.

- The reductions in flexural strength for GC mixes inclusion WPA or WA are close to those reductions in compressive strength for these mixes and less than the reductions in splitting tensile strength.

- From the present obtained results, it can be concluded that the GC mix with partial replacement of FA by WPA up to $50 \%$ or WA up to $25 \%$ can be satisfactorily used in preparation of the GC. Besides, utilizing these materials in developing GC has economic and environmental benefits.

\section{References}

Abdulkareem, O.A., Ramli, M. \& Matthews, J.C. (2019). Production of geopolymer mortar system containing high calcium biomass wood ash as a partial substitution to fly ash: an early age evaluation. Composites Part B: Engineering, 174, 106941. https://doi. org/10.1016/j.compositesb.2019.106941

ASTM International [ASTM] (2002). Standard test method for flexural strength of concrete (ASTM C78-02). West Conshohocken (PA): ASTM International.

ASTM International [ASTM] (2004). Standard test method for splitting tensile strength of cylindrical concrete specimens (ASTM C496-04). West Conshohocken (PA): ASTM International.

ASTM International [ASTM] (2005). Standard test method for slump of hydraulic-cement concrete (ASTM C143/C 143M-05a). West Conshohocken (PA): ASTM International.

ASTM International [ASTM] (2008). Standard specification for coal fly ash and raw or calcined natural pozzolan for use in concrete (ASTM C618-08a). West Conshohocken (PA): ASTM International.

ASTM International [ASTM] (2017). Standard specification for chemical admixtures for concrete (ASTM C494-C494M). West Conshohocken (PA): ASTM International.

Astutiningsih, S. \& Liu, Y. (2005). Geopolymerisation of Australian slag with effective dissolution by the alkali. In Proceedings of the World Congress Geopolymer (pp. 
69-73). Geopolymer Institute: Saint Quentin, France.

Bai, J., Chaipanich, A., Kinuthia, J.M., O'Farrell, M., Sabir, B.B., Wild, S. \& Lewis, M.H. (2003). Compressive strength and hydration of wastepaper sludge ash-ground granulated blastfurnace slag blended pastes. Cement and Concrete Research, 33(8), 1189-1202.

British Standards Institute [BSI] (2000). Testing concrete. Part 116: Method for determination of compressive strength of concrete cubes (BS 1881-116:1983). London: British Standards Institute.

Chowdhury, S., Maniar, A. \& Suganya, O.M. (2015). Strength development in concrete with wood ash blended cement and use of soft computing models to predict strength parameters. Journal of Advanced Research, 6(6), 907-913.

Davidovits, J. (2020). Geopolymer chemistry and applications. 5th ed. Saint-Quentin, France: Geopolymer Institute.

Duxson, P., Fernández-Jiménez, A., Provis, J.L., Lukey, G.C., Palomo, A. \& van Deventer, J.S. (2007). Geopolymer technology: the current state of the art. Journal of Materials Science, 42(9), 2917-2933.

Ekaputri, J.J. \& Junaedi, S. (2017). Effect of curing temperature and fiber on metakaolin-based geopolymer. Procedia Engineering, $171,572-583$.

Etiegni, L. \& Campbell, A.G. (1991). Physical and chemical characteristics of wood ash. Bioresource Technology, 37(2), 173-178.

Fairbairn, E.M., Americano, B.B., Cordeiro, G.C., Paula, T.P., Toledo Filho, R.D. \& Silvoso, M.M. (2010). Cement replacement by sugar cane bagasse ash: $\mathrm{CO}_{2}$ emissions reduction and potential for carbon credits. Journal of Environmental Management, 91(9), 1864-1871.

Fernandez-Jimenez, A.M., Palomo, A. \& Lopez-Hombrados, C. (2006). Engineering properties of alkali-activated fly ash concrete. $A C I$ Materials Journal, 103(2), 106-112.

Fernández-Jiménez, A., García-Lodeiro, I. \& Palomo, A. (2007). Durable characteristics of alkali activated fly ashes. Journal of Material Sciences, 42, 3055-3065.

Frías, M., García, R., Vigil, R. \& Ferreiro, S. (2008). Calcination of art paper sludge waste for the use as a supplementary cementing material. Applied Clay Science, 42(1-2), 189193.

García, R., Villa, R.V. de la, Vegas, I., Frías, M. \& Rojas, M.S. de (2008). The pozzolanic properties of paper sludge waste. Construction and Building Materials, 22(7), 1484-1490.

Gartner, E. (2004). Industrially interesting approaches to "low- $\mathrm{CO}_{2}$ " cements. Cement and Concrete Research, 34(9), 1489-1498.

Hardjito, D., Wallah, S.E., Sumajouw, D.M. \& Rangan, B.V. (2004). On the development of fly ash-based geopolymer concrete. Materials Journal, 101(6), 467-472.

Iraqi Central Agency for Standardization and Quality Control [ICASQC] (1984). Iraqi standards for natural aggregate resources for concrete (IQS 45/1984). Baghdad: Iraqi Central Agency for Standardization and Quality Control (translated from Arabic edition).

Ishimoto, H., Origuchi, T. \& Yasuda, M. (2000). Use of papermaking sludge as new material. Journal of Materials in Civil Engineering, 12(4), 310-313.

Letelier, V., Henríquez-Jara, B.I., Manosalva, M. \& Moriconi, G. (2019). Combined use of waste concrete and glass as a replacement for mortar raw materials. Waste Management, 94, 107-119.

Luga, E. \& Peqini, K. (2019). The Influence of Oxide Content on the Properties of Fly Ash/Slag Geopolymer Mortars Activated with NaOH. Periodica Polytechnica Civil Engineering, 63(4), 1217-1224.

Malaszkiewicz, D. \& Jastrzebski, D. (2018). Lightweight self-compacting concrete with sintered fly-ash aggregate. Scientific Review - Engineering and Environmental Sciences, 27(3), 328-337.

Mehta, A. \& Siddique, R. (2018). Sustainable geopolymer concrete using ground granulated blast furnace slag and rice husk ash: Strength and permeability properties. Journal of Cleaner Production, 205, 49-57.

Mozaffari, E., Kinuthia, J.M., Bai, J. \& Wild, S. (2009). An investigation into the strength development of wastepaper sludge ash blended with ground granulated blastfurnace slag. Cement and Concrete Research, 39(10), 942-949. 
Naik, T.R., Kraus, R.N., \& Siddique, R. (2003). Controlled low-strength materials containing mixtures of coal ash and new pozzolanic material. Materials Journal, 100(3), 208-215.

Pachamuthu, S. \& Thangaraju, P. (2017). Effect of incinerated paper sludge ash on fly ash-based geopolymer concrete. Građevinar, 69(9), 851-859.

Rangan, B.V. (2008). Fly ash-based geopolymer concrete. Perth: Curtin University of Technology.

Risdanareni, P., Karjanto, A. \& Khakim, F. (2016). Physical properties of volcanic ash based geopolymer concrete. Materials Science Forum, 841, 1-6.

Ryu, G.S., Lee, Y.B., Koh, K.T. \& Chung, Y.S. (2013). The mechanical properties of fly ash-based geopolymer concrete with alkaline activators. Construction and Building Materials, 47, 409-418.

Shi, C., Wu, Y., Riefler, C. \& Wang, H. (2005). Characteristics and pozzolanic reactivity of glass powders. Cement and Concrete Research, 35(5), 987-993.

Tam, V.W., Soomro, M. \& Evangelista, A.C.J. (2018). A review of recycled aggregate in concrete applications (2000-2017). Construction and Building Materials, 172, 272-292.

Thaarrini, J. \& Ramasamy, V. (2016). Properties of foundry sand, ground granulated blast furnace slag and bottom ash based geopolymers under ambient conditions. Periodica Polytechnica Civil Engineering, 60(2), 159-168.

Turner, L.K., \& Collins, F.G. (2013). Carbon dioxide equivalent $\left(\mathrm{CO}_{2}\right.$-e $)$ emissions: $\mathrm{A}$ comparison between geopolymer and OPC cement concrete. Construction and Building Materials, 43, 125-130.

Udoeyo, F.F., Inyang, H., Young, D.T. \& Oparadu, E.E. (2006). Potential of wood waste ash as an additive in concrete. Journal of Materials in Civil Engineering, 18(4), 605-611.

\section{Summary}

Use of waste paper ash or wood ash as substitution to fly ash in production of geopolymer concrete. Large quantities of paper and wood waste are generated every day, the disposal of these waste products is a problem because it requires huge space for their disposal. The possibility of using these wastes can mitigate the environmental problems related to them. This study presents an investigation on the feasibility of inclusion of waste paper ash (WPA) or wood ash (WA) as replacement materials for fly ash (FA) class $\mathrm{F}$ in preparation geopolymer concrete (GC). The developed geopolymer concretes for this study were prepared at replacement ratios of FA by WPA or WA of $25,50,75$ and $100 \%$ in addition to a control mix containing $100 \%$ of FA. Sodium hydroxide $(\mathrm{NaOH})$ solutions and sodium silicate $\left(\mathrm{Na}_{2} \mathrm{SiO}_{3}\right)$ are used as alkaline activators with $1 \mathrm{M}$ and $10 \mathrm{M}$ of sodium hydroxide solution. The geopolymer concretes have been evaluated with respect to the workability, the compressive strength, splitting tensile strength and flexural strength. The results indicated that there were no significant differences in the workability of the control GC mix and the developed GC mixes incorporating WPA or WA. Also, the results showed that, by incorporating of $25-50 \%$ PWA or $25 \% \mathrm{WA}$, the mechanical properties (compressive strength, splitting tensile strength and flexural strength) of GC mixes slightly decreased. While replacement with $75-100 \%$ WPA or with $50-100 \%$ WA has reduced these mechanical properties of GC mixes. As a result, there is a feasibility of partial replacement of FA by up to $50 \%$ WPA or $25 \%$ WA in preparation of the geopolymer concrete. 
Authors' address:

Haider Mohammed Owaid

(https://orcid.org/0000-0001-7252-5875)

University of Babylon

College of Engineering

Department of Civil Engineering

Al-Hillah - Al-Najaf Road, Babylon

Iraq

e-mail: eng.haider.ma@uobabylon.edu.iq

haidernccl@yahoo.com

Muna M. Al-Rubaye

University of Babylon

College of Engineering

Department of Civil Engineering

Al-Hillah - Al-Najaf Road, Babylon

Iraq

e-mail: eng.muna.mohamed@uobabylon.edu.iq

Haider M. Al-Baghdadi

University of Babylon

College of Engineering

Department of Civil Engineering

Al-Hillah - Al-Najaf Road, Babylon

Iraq

e-mail: eng.haider.m@uobabylon.edu.iq 